\title{
GCU
}

Glasgow Caledonian

University

University for the Common Good

\section{Rethinking academic literacies: a conceptual development based on teaching practice}

Canton, Ursula; Govan, Michelle; Zahn, Daniela

Published in:

Teaching in Higher Education

DOI:

$10.1080 / 13562517.2017 .1414783$

Publication date:

2018

Document Version

Author accepted manuscript

Link to publication in ResearchOnline

Citation for published version (Harvard):

Canton, U, Govan, M \& Zahn, D 2018, 'Rethinking academic literacies: a conceptual development based on teaching practice', Teaching in Higher Education, vol. 23, no. 6, pp. 668-684.

https://doi.org/10.1080/13562517.2017.1414783

\section{General rights}

Copyright and moral rights for the publications made accessible in the public portal are retained by the authors and/or other copyright owners and it is a condition of accessing publications that users recognise and abide by the legal requirements associated with these rights.

Take down policy

If you believe that this document breaches copyright please view our takedown policy at https://edshare.gcu.ac.uk/id/eprint/5179 for details of how to contact us. 
Rethinking Academic Literacies. A Conceptual Development Based on Teaching Practice

Ursula Canton $^{1}$, Michelle Govan ${ }^{2}$, Daniela Zahn ${ }^{2}$

${ }^{1}$ Glasgow Caledonian University; ${ }^{2}$ Independent Researcher

School of Engineering and Built Environment, Cowcaddens Glasgow G4 0BA, 0044141 2731177, Ursula.Canton@gcu.ac.uk 


\title{
Rethinking Academic Literacies. A Conceptual Development Based on Teaching Practice
}

\author{
Academic Literacies, the most influential conceptual framework for writing prac- \\ titioners at UK universities, is closely related to widening participation. At the \\ same time, writing support is often justified with the argument that written com- \\ munication is among the most important employability skills for graduates. \\ While these concepts are often used simultaneously, their underlying premises \\ are not necessarily congruent. This paper reflects on a writing intervention that \\ highlighted the difficulties that can arise from a seeming 'pick and mix' use of \\ these two frameworks, Academic Literacies and writing as an Employability \\ Skill. Based on this analysis of the practice of teaching writing at a post-92 uni- \\ versity, it establishes the need for an expanded, theoretical framework for writing \\ support.
}

Keywords: academic literacies; writing support; employability; discourse community

\section{Introduction}

Writing support can be found in most UK universities, especially post-1992 Higher Education Institutions (HEIs), and has attracted growing research interest over the last 20 years. Its growing presence is often explained as a reaction to the development towards mass Higher Education (Ganobcsik-Williams 2006, 6): the decrease in personal attention students can receive in such a system, as well as their divergent backgrounds and motivations mean that an almost automatic academic socialisation process has become impossible. Since physical access to HE is insufficient, universities also need to make efforts to give non-traditional students epistemological access (Morrow 1993 cited in Leibowitz et al. 1997, 7). Writing support is often seen as part of this effort to support students' successful engagement with university. This notion is one of the underlying premises of Academic Literacies (Lea and Street 1998 or Lillis 2001), a conceptual framework that is widely used among UK writing practitioners. 
Additionally, writing support can be promoted (and resourced) as part of an employability agenda (as described, for example, by Borg and Deane 2011). Preparing students for graduate employment is especially relevant to post-92 universities, such as Glasgow Caledonian University (GCU), who define themselves as 'employment led' (GCU 2013), but can also be found at what might be described as more traditional, research-led universities: in the six lists of graduate attributes found on the websites of Russell Group universities communication skills also take a prominent place. Thus, the importance of written and verbal communication skills for graduate employment is another factor behind the increase in writing support. In practice both aims, widening participation and supporting the development of employability skills, are important for the promotion, justification and funding for writing support in Higher Education (HE), and they are often cited together (e.g. Rukhsana and MacMahon 2006). Their impact on teaching practice, however, is not always clear and the relationship between an Academic Literacies approach and the notion of writing as an Employability Skill is rarely explored.

Such flexible acknowledgement and lack of clear distinction can be problematic, as the theoretical underpinnings behind the two approaches are markedly different, if not contradictory, in their educational ideologies and goals, as well as their understanding of writing and literacy (for more detail see below). These differences seem to be acknowledged implicitly when academic writing practitioners emphasise the importance of an Academic Literacies framework for their pedagogical decisions on the design of curricula and teaching and learning activities. Yet, simultaneously they refer to writing as an Employability Skill for pragmatic reasons, ranging from obtaining funding for writing support to motivating students to participate in the support offered. Nevertheless, the implications of this co-existence of influences and the potentially contradictory 
premises that underlie them are hardly ever made explicit or subjected to detailed analysis.

\section{Methodology and Outline}

This paper analyses this conundrum for writing practitioners, and suggests consequences for the conceptual basis and practice of writing development. The analysis draws on observations on writing classes at GCU which resulted in a delayed and partial achievement of the main learning outcome for the students involved. The classes were delivered at GCU as part of the BEng Digital Security, Forensics \& Ethical Hacking programme to 11 undergraduate students in the third year of this four-year programme. Five classes of three hours each were developed and taught by a writing specialist (UC) from the School of Engineering and Built Environment's Learning Development Centre (LDC) in close collaboration with the Director of Studies (DoS) for the BEng (MG). To appraise the impact of these classes, we collected data through semi-formal and informal means, such as our own observations, students' feedback given informally through conversation and email, and a one minute post-it survey conducted immediately after the classes ${ }^{1}$. The emerging evidence echoed previous teaching experience where the main learning outcomes for our writing work were not achieved. This gave us the impression that it was 'indicative of underlying trends, motives and structures' (Tripp 1993, 25). As a result, we considered these writing classes to be an event that deserved to be 'rendered critical through analysis' (ibid) and subjected the data we had collected

\footnotetext{
${ }^{1}$ Ethical approval for this study was granted by the School's Ethics Committee. Students' consent was given for the use of their texts, contributions to classes, individual appointments, and feedback. Students were not disadvantaged in terms of teaching and feedback for not consenting to participate.
} 
to hermeneutic analysis, or interpretative analysis as outlined, e.g. by Yanow (2007) in the area of public policy.

Our analysis identifies the unexplored co-existence of two conceptual frameworks, an Academic Literacies approach and writing as an Employability Skill, and explores the inconsistencies resulting from this double-bind. The possibility that the underlying theoretical approaches are incompatible means that our analysis cannot limit itself to prompting changes in teaching practice. This insight necessitates wider epistemological consequences. On this basis we propose an expansion of our conceptual framework and offer a tentative outline of a modified Academic and Professional Literacies (APL) approach, which attempts to reconcile the emancipatory and transformative approach advocated in Academic Literacies with the students' own focus on employability skills.

\section{The Writing Classes}

The curriculum was designed in response to observations made by the DoS, as well as an indicative text analysis of a writing sample, which comprised short individual research reports. The text analysis by the writing specialist revealed three areas of difficulties:

- failure to see writing as social interaction,

- lack of awareness of discourse conventions, and

- problems with the mechanics of writing.

The following description explains each difficulty in order of their importance for the design of this curriculum. It also presents the learning outcomes that arose from them and briefly describes the learning and teaching activities employed to achieve them. 
(1) Writing as a Social Act

On a fundamental level, the indicative text analysis and the DoS' observations suggested that students saw writing as little relevant. They failed to consider the impact of their texts on potential readers, both in terms of successfully communicating with them, and in terms of the impression readers might acquire of them based on reading their texts. Towards their DoS they expressed the view that writing was an odious task, which was imposed on them by educational institutions, but which had little impact on their development as technical experts. In line with these comments, the short research reports they had submitted could, without exception, be classified as 'writer-based prose' (Swales. 1990, 64): the texts betrayed no consideration of the purpose for writing (explaining a technical issue) or awareness of potential audiences (someone unfamiliar with the specific issue). Very few explained why they had chosen their topic, or why it was relevant, and some of them bore a remarkable resemblance to stream of consciousness, devoid of any consideration of the needs of their readers. Their overly personal style, including regular reader addresses ('If you can find the code, you can then...') was as inappropriate for an academic or professional audience, as were the mainly unreflective narrative accounts of their own endeavours for an assignment that should demonstrate understanding on a more abstract level ('In order to analyse the Mail App properly, I decided to set up my own example'). Where the texts expressed awareness of a reader, the informality of this address showed that the students either misunderstood their relationship with the readers, or were unable to express this relationship appropriately ('to make things clearer and more interesting (hopefully you haven't fallen asleep already)'). The most important learning outcome for the classes was thus to develop the students' understanding of writing as a social act in which readers and writers 
negotiate meaning and identities (Gee 2008, 13). Instead of seeing writing as separate from their development as processionals in their field, the aim was to help them see themselves as 'an active part of language' (Clark and Ivanič 1991, 171), or as expressing this growing expertise through writing. The first two sessions, therefore, offered exercises that prompted students to analyse the intended audience(s) of finished texts and of writing prompts, to consider the needs of different audiences and to develop high level plans (Deane et al. 2008).

\section{(2) Conventions of Discourse Communities}

On a formal level, the students' reports also reflected their lack of awareness of important conventions for academic or professional reports, specifically the need to write in an impersonal style. In addition, sources were rarely acknowledged, with the exception of a few texts that included a list of uncommented URLs at the end. The second learning outcome was thus to familiarise students with the conventions of impersonal writing and referring to sources, both of which are found in academic texts and many professional genres. In line with the first learning outcome, conventions were always explained as the result of the values prevalent in specific Discourse Communities. Referencing, for example, was introduced as the result of the high value placed on transparency and independent critical thinking. Therefore, the exercises for the next one and a half classes established a specific writing context before asking students to recognise these conventions, to identify their purpose and to apply them by rewriting a text.

\section{(3)Mechanics of Writing}

Finally, on the surface level of the analysis, the DoS reported significant problems with the mechanics of writing, and the analysis of the research reports confirmed that they 
contained numerous syntactical errors, as well as common spelling mistakes. Improving students' ability to write complete and correct sentences, and to differentiate the spelling of popular homonyms, such as 'their', 'they're' and 'there' was chosen as the third learning outcome. Although such lower-level concerns ${ }^{2}$ have a less significant impact on students' ability to communicate than their disregard for the audience, addressing them was considered important, because improvements are more immediately noticeable to both students and their subject lecturers.

\section{Feedback after the Classes}

For the small post-it survey, the students were asked to answer the following questions: 1) What was the most useful aspect of the classes? 2) What was the least useful one? 3) Had any of the exercises from the classes changed their writing in other contexts? 4) If so, which one and what did it change? In which context? Although the small number of participants makes a formal quantitative analysis impossible, matching the answers to the three learning outcomes suggests a trend (see Table 1$)^{3}$ : the exercises on the mechanics of language were seen as most useful, or used later more often than those building awareness of writing as a social act. The latter, on the contrary, were most often found to be the least useful ones. The semi-formal evaluation suggested that the main learning outcome, increasing their awareness of writing as a social act and helping them understand the role of 'social interactions [in] make[ing their] texts effective' (Hyland 2005, ix), had not been achieved after the intervention. This was echoed by the au-

\footnotetext{
${ }^{2}$ A term widely used in literature on composition studies (McAndrew, Reigstad and Strickland [2001] or Purdue University [2013]), but rarely defined in further detail.

${ }^{3}$ Some answers referred to other aspects, such as the temperature of the room, others were left blank.
} 
thors' observations from emails and conversations with the students, and an informal analysis of texts students wrote immediately following the intervention.

Table 1: Student Answers to Feedback Questions

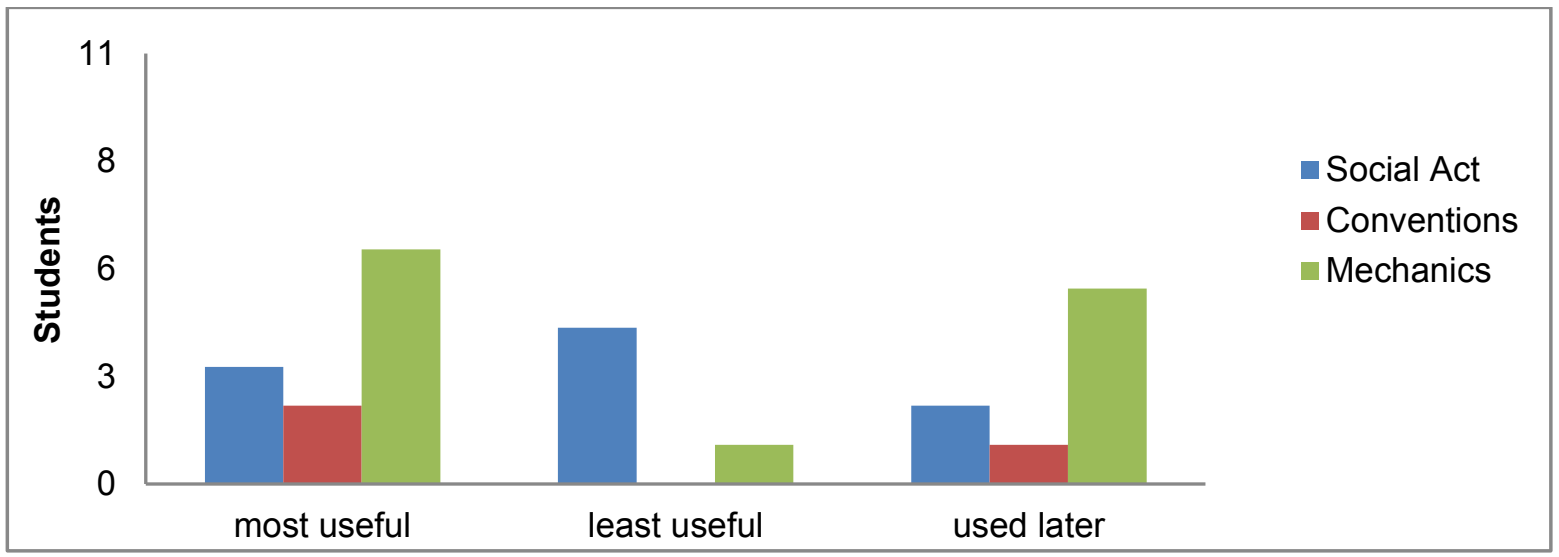

\section{Analysis: First Iteration}

Drawing on literature on the learning process, it is possible to identify aspects that could explain why the main learning outcome was not achieved, at least in the first instance. The first is the knowledge or skill to be learned: less complex, rule-bound lowerorder concerns are easier to learn than highly complex and context-dependent higherorder concerns. The mechanics of language, especially simple rules, e.g. different spellings of homonyms, are easier to learn than manipulating the relationship between writer and readers. As a result, these aspects might have proven to be the most popular and transferable ones immediately after the intervention.

Time could also play a role: the writing classes took place during the third year of a four year programme, and following Lave and Wenger's concept of Communities of Practice (CoP) the intervention was planned assuming that, at this point, students had already experienced a considerable ‘engagement in [academic] practice' (Lave and Wenger 1991, 93). Nonetheless, the fact that in their first two years of their programme students encountered few longer writing tasks, and were required to read relatively little 
in terms of academic literature could suggest the classes were still too early. It was assumed that delivering the intervention in time to prepare the students for longer assignments would help them avoid making unnecessary mistakes. On the other hand, Lave and Wenger suggest that 'engagement in practice may well be a condition for the effectiveness of learning' (Lave and Wenger. 1991, 93; italics by the authors). This could indicate that only the experience of this engagement, i.e. producing longer assignments themselves, offers a fruitful basis for learning. In the tradition of reflective practice, this would thus suggest specific changes to the writing classes, specifically a slight change in timing.

\section{Including Further Observations in the Analysis}

A year later the initial, rather sobering result was slightly modified. After some of the students had received negative reactions to their writing for work placements, the same group of students voluntarily participated in the whole series of writing classes delivered to the next cohort. Over half of them, including all those who encountered problems during placements, also asked for one-to-one support from the LDC, and their questions in these sessions supported the impression that they had developed greater awareness of the social dimension of writing. These observations sparked a second iteration of analysis, which came to focus on some of the basic tenets of the conceptual basis of the writing intervention. Initially it focused, however, on the simplest explanation for the belated changes in attitude towards writing, which is time: after noticing increased competence in the surface aspects of writing, it could be argued that students felt more motivated and able to focus on the more complex higher-order concerns, partly because this learning process was slower, and partly because their successful initial learning created a fruitful basis for future learning (Biggs and Tan. 2007, 37). 
A more incisive change than a potentially gradual development over time was students' experience with other Discourse Communities: the professional Communities of Practice (CoP) many of them met during placements, and their individual representatives who came to deliver talks to the students at the university. These new experiences also seemed highly relevant, because all the writing-related experiences communicated to the DoS by the students and industry partners related to work-place writing, not their academic assignments. It thus seems plausible that these experiences played an important part in increasing students' motivation to engage with writing as a social act.

Focusing on these different Discourse Communities brings to the fore the hitherto unacknowledged coexistence of different conceptual frameworks that influenced the writing intervention: Employability Skill and an Academic Literacies approach. For the DoS, employability skills were at the heart of the undergraduate programme she designed to reflect the multidisciplinary skill set (Irons, Stephen and Ferguson 2009) required to address the challenges of developing digital forensics (Palmer 2001). Taking into account the wide range of legal, social, ethical and professional responsibilities of practitioners in the field (GCHQ. 2014, 14), she concluded that graduates not only needed a thorough understanding of current and emergent technologies, but also a range of other employability skills. Among those, communication takes a prominent place, as professionals in digital security need to report their findings in a manner which gives credibility to their work for a range of audiences (Govan 2014a), be it in the legal system as expert witnesses for digital forensic evidence, in organisations and companies whose infrastructure they protect, and, sometimes, among the general public where they can raise awareness of cyber security (UK Government 2011, 23). We thus instigated the writing classes with a clear focus on writing as an Employability Skill, and aimed at 
integrating this aspect into the curriculum, especially in the first sessions, which used examples of writing from academic, professional and public discourses on digital security. The importance of writing for professional communication was further emphasised to students, as the classes were delivered as part of an out-duction process, i.e. a formal programme designed to support the transition from university into internships and graduate employment (Govan 2014b).

At the same time the classes were strongly influenced by the writing practitioner's commitment to an Academic Literacies framework, visible in the strong emphasis on making language visible (Lillis 2001) and helping students analyse the role of writing as social interaction in which writers' social identities (Gee 1999, 4) are expressed. Similar to the way in which Lea and Street (1998) see Academic Literacies as encapsulating a study skills approach and an academic socialisation approach, this writing intervention related the foci of the other two approaches (i.e. the mechanics of writing and its conventions) to the communicative purposes (Askehave and Swales 2001) and practices they serve in different Discourse Communities (Swales 1990, 9).

Contrary to the emphasis on writing as an Employability Skill described above, the conceptual framework that shaped our approach is thus primarily focused on academic writing. A similar orientation could be observed in the texts we used: although the conventions that were included, like marking sources, can also be found in some professional genres, most of the examples we used stemmed from academic texts, as did the examples used to teach the mechanics of writing. This choice was partly based on the hope that enabling students to apply their new knowledge in their upcoming, longer assignments would increase their motivation for future learning (Dearnley and Matthew 2007, 388). Nonetheless, the pragmatic reason that we were more familiar with academic texts might have further contributed to this choice. Nonetheless, this could have coun- 
tered our commitment to developing skills students would need for their career beyond the university, and could thus have reduced the perceived relevance of the classes for them.

Analysing the ways in which the concepts of Academic Literacies and writing as an Employability Skill have impacted on the writing classes demonstrates that their unacknowledged co-existence means that students received mixed messages about the intervention. Following Schön's understanding of reflective practitioners, the logical consequence of "reflect[ing] on the understandings which have been implicit in [these] actions" would be to critically appraise them and "embod[y them] in further action" (Schön 1991, 50). Further analysis of these conceptual frames reveals, however, that the contradictions present in them are of relevance beyond this particular example of teaching practice.

\section{The Tension between Employability and Academic Literacies}

Tensions arise not from minor conceptual details of the two approaches. They are deeply rooted in two of the most important elements of any teaching intervention: the nature of the matter to be taught and the desired learning outcomes. Although teaching writing includes many other aspects, such as teaching processes, at its core is teaching students how to create meaning through written language. The notion of language underlying this process is thus essential, and on this point the concept of Academic Literacies explicitly rejects the simplistic understanding of language that underlies most calls to teach writing as an Employability Skill. Although they are mainly independent from each other, most proponents of this approach identify problems with lower-order concerns that employers easily recognise and often bemoan, such as punctuation, spelling or sentence structure (Middleton 2011). Academic Literacies, on the other hand, counter the notion that students lack simple, discrete skills and emphasise the "institutional 
structures and disciplinary cultures" (Klein and Boscolo 2016, 324) that influence discourses. The focus here is thus on making language visible (Lillis 2001) and helping students understand the ways in which writing shapes and supports their social interactions.

This difference in the understanding of language, or in other words the subject matter to be taught, is closely related to a fundamentally different notion of the learning outcomes of writing interventions in HE. The list of discrete employability skills students are seen to be lacking is mainly informed by research into the skills employers require from (Davies 2009 and Diamond et al. 2011, 8) or miss in recent graduates, especially in technical subjects (Archer and Davison 2008). Hence, teaching these skills at university is a way of ensuring that HEIs fulfil their role in 'providing students with an education' (Reaney 2016; italics by the authors) and to prepare skilled employees whose work contributes to maintaining the economy. Such an understanding of education is typical of a HE system that espouses market-based values (Kezar and Bernstein-Sierra 2016, 332), but is particularly prominent in post-92 universities that derive their raison d'être from a tradition of 'Ausbildung,' or training, rather than 'Bildung,' or a Humboldtian model of education (Tennebaum 2012). Because these universities offer degrees that 'correspond to recognised professional career pathways that focus on technical and professional specialisation and skill sets that are particularly in demand' (GCU 2013), they are more likely to assume that 'students decide to go to university for one reason alone - to improve their chances of getting a better job when they leave' (Reaney 2016).

The concept of Academic Literacies, on the other hand, is deeply rooted in the notion of education as a transformative experience. If this approach emphasises the role of writing in establishing social relationships, it does so partly with a view of 
transforming students' understanding of their own environment. Beyond that it encourages students to ‘talk back' (Lillis 1997, 158). Academic Literacies regard critical investigation of discourse conventions as the basis for allowing those previously excluded by prevalent power structures to challenge these to their advantage by asking questions about the way discourses reflect and support social values and (power) relationships. Greater understanding of the role language plays in shaping their social environment helps students take an active role in shaping it (see, e.g. Lillis 1997 or Ivanič 1998). This means that it aims not solely at transforming students' understanding of discourses, but also works towards "transformation of the discourses of the academy to better meet the diversity of students' experiences and identities" (Coffin and Donohue 2012, 72). The framework's critical approach to writing thus challenges the status quo, the accepted (power) structures, values and forms of participation, in academia itself.

This emancipatory claim shows Academic Literacies' roots in new literacies, which established the link between literacy and "the various social groups and institutions that underwrite various types of texts and ways of interpreting them" in order to challenge the "social status quo" (Gee 2008). This sense of education as a potentially liberating, even radical tool, places Academic Literacies in a long lineage of thinkers and practitioners who see education first and foremost as a transformative process instead of transference of knowledge (Freire 1985). Reconciling this aim and understanding of language with those underlying common assumptions about writing as an Employability Skill seems almost impossible.

This interpretation raised uncomfortable questions about the appropriateness of an Academic Literacies framework for the teaching of writing at GCU, and potentially, other HEIs with a similar profile: for the authors it is highly uncomfortable to subscribe to the narrow notion of writing solely as an Employability Skill. This is based in a deep 
rooted conviction that education is not simply a commodity which is traded in a market system, but a human right. Further to that, the simplistic concept of language also counters research evidence. The impression that students were far more motivated to work on their writing once they had experienced writing for future colleagues during placements, on the other hand, confirms the impression gained by other academics working at post-92 HEIs: many students are primarily interested in joining a professional community, not academic ones. Their participation in academic discourses is a necessary step to achieve this aim, not a goal in itself, and, as a consequence, they are less motivated to participate fully in them. If the emancipatory claim of Academic Literacies is taken seriously, however, this raises an urgent question: is it possible or desirable for those teaching in this framework to impose a transformative process on those they educate? In other words, the reflection presented here suggests that it might be necessary to subject this conceptual framework to critical scrutiny, as, in its current form, it might be inadequate for this particular environment.

\section{Digging Deep: the Relationship between writing as an Employability and Ac- ademic Literacies}

A good starting point for a thorough analysis of this potential incongruity between our conceptual framework and our students' aspirations is taking a closer look at the element which they seem to reject: the focus on developing their identities as legitimate, peripheral members of academic Communities of Practice (CoP; Lave and Wenger 1991). By focussing on 'academic norms and conventions as well as institutional policy, particularly in relation to issues of identity and power' (Coffin and Donohue 2012, 65; italics added by the authors), Academic Literacies follow a common pattern in educational research. Despite the fact that Lave and Wenger's (1991) concept was developed in the context of apprenticeships, i.e. professional learning, its use in the context of 
HE research focuses almost exclusively on students' transition into academic CoPs. This means that a concept developed from situations where 'a learning curriculum unfolds in opportunities for engagement in practice' (Lave and Wenger 1991, 93) is applied to HE contexts, where strongly theoretical, explicit teaching is predominant. As Lea (2005) discusses, this shift can be problematic. The same author questions "how far students and their tutors really do belong to the same communities" (Lea 2005, 193), but, to our knowledge, this question has found little resonance in other authors (for a notable exception see Gourlay 2009. In other words, the incongruence identified above stems from an assumption that underlies a significant proportion of research in education, and is not unique to Academic Literacies.

This insight then suggests that any attempt at reconciling Academic Literacies with our students' expectations needs to address the underlying assumption that students want to participate fully in an academic $\mathrm{CoP}$, rather than their future professional CoPs. At this stage, it is important to emphasise that this endeavour is not meant to reduce the importance of research based on this assumption. It is beyond any doubt that the potential difficulties of successfully developing a positive student identity, especially for students from non-traditional backgrounds (Lillis 2001), need to be addressed to enable students to be successful, both in terms of their personal development as lifelong learners, as well as on measurable aspects, such as progression and retention. Reflection on the teaching intervention described above does suggest, however, that the exclusive nature of the focus on academic CoPs might be problematic at institutions like GCU. Our seemingly unacknowledged assumption about our students' desire to join academic CoPs might, inadvertently, reflect our own identities as researchers for whom our studies marked the beginning of a transition from legitimate peripheral participation to full participation as academics. It does not take into account that most of our students 
will never experience this full participation, nor do they necessarily want to do so. For them, their student identity might always be a transitory one, a necessary step on the path towards full participation in the professional CoPs they want to join. In addition to thinking about transition into (and less so out of) this student identity, it might thus be necessary to conceptualise university studies, especially at undergraduate level, as a phase of transition per se.

A re-conceptualisation of $\mathrm{HE}$ as a transitional phase can have an impact on many aspects of education research; in the context of this paper, it allows us to approach the conflict caused by the apparent contradictions of the two approaches to the teaching of writing from a different angle: instead of focussing on the contradictory elements in Academic Literacies and writing as an Employability Skill, it allows us to focus on their orientation towards different Discourse Communities and students' motivation to participate in them. In other words, we might have misinterpreted our students' failure to engage with the social aspects of language before they could see the relevance for their participation in professional discourse communities. Their behaviour might not have been lack of interest in making language visible and challenging "institutional practices, power relations and identities" (Lea and Street 1998, 158). This interpretation suggests a more pertinent question: which (institutional) practices, power relations and identities matter enough to our students to raise their interest in further analysis and should, therefore, be at the focus of teaching writing? Reformulating the approach leads away from the question of whether an Academic Literacies framework can be appropriate for our students and towards the question of whether we can expand it towards the Discourse Communities that matter to them. Should Academic Literacies become Academic and Professional Literacies? 
Such an expansion would acknowledge the importance of both academic and professional discourses, of 'access [to] and critical engagement' with these discourses (The New London Group 1996, 67); yet, it is qualitatively different from the inconsistent use of Academic Literacies and writing as an Employability Skill identified in the writing intervention examined in this paper. Instead, this reflection on practice and its conceptual basis should lead to a systematic application of the principles of Academic Literacies to the area of workplace writing. That is, all its main characteristics should be applied to additional Discourse Communities, including the notion of making language in all its complexity visible and the aim of using it to help writers understand how they are participating in social acts that shape their relationships with other members of a Discourse Community through writing. Rather than abandoning some of the principles of Academic Literacies, it means reclaiming the development of emergent professional writer identities by rejecting the notion that becoming a professional just means accumulating discrete, marketable skills.

\section{On the Possibility of Academic and Professional Literacies (APL)}

The development of an Academic and Professional Literacies approach would be a significant conceptual development, not only in terms of its potential usefulness, but also in terms of the challenge it poses. Yet, there are some aspects that offer hope that such an undertaking is possible.

First of all, the use of the plural 'literacies' indicates that the current concept already acknowledges the diversity of writing tasks students encounter in different disciplines and institutions (Catt and Gregory 2006, 18). Expanding the critical interrogation of the social functions of writing and of the textual forms that realise these functions from writing in academic to professional contexts is thus relatively straightforward in theoretical terms. If students had access to the writing practice of relevant Discourse 
Communities, they could also learn to 'interpret the constituent elements of the[se] environments' (Anson and Forsberg 1990, 225). Similarly, the linguistic means that characterise different registers could be examined in the context of a wider range of different professional and academic genres in which they are substantiated (Lee 2001).

Another opportunity is the idea that exposure to a greater variety of different discourse constellations and texts could be beneficial to teaching the skills required for critical analysis: more and different examples could make it easier to convince students that there is no 'right' way to write which they can simply emulate, but that successful written communication depends on the context, audience and purpose. Consequently they might be more open to the idea of developing analytical skills, which allow them to establish the link between "social action and textual regularity" (Dias et al. 1999, 19) and adapt their writing to different circumstances. In addition, such variety of discourses and Discourse Communities makes the complexity of writing more visible. Through this, it could become easier to convince those responsible for programme and curriculum design that Academic and Professional Literacies need to be fully embedded into students' curricula.

The aspects that favour the development of an Academic and Professional Literacies framework are, nevertheless, matched by practical and conceptual difficulties. In the first instance, this would require substantial changes in the relevant programmes of study: if the aim is to help students become more versatile members of academic and professional Discourse Communities, their knowledge of and involvement in these communities needs to be strengthened. The enhanced outduction programme of the BEng Digital Security, Forensics \& Ethical Hacking, for example, demonstrated a range of different ways in which professionals from the field of digital security and forensics contributed to students' learning (Govan. 2014b). These could be expanded and 
writing specialists could support and encourage this process; it is clear, however, that it has to be led by subject lecturers that develop programmes of study. This means that the development and application of an Academic and Professional Literacies framework depends on factors that are beyond the control of those teaching writing.

Reducing the focus on academic genres in writing-based assessment is equally reliant on the collaboration with, or even leadership from those teaching their own academic subjects. In addition, it is not possible to entirely eliminate differences between writing in $\mathrm{HE}$ and writing in the workplace, such as the focus on acting when writing in the workplace and on learning for writing in HE (Dias et al. 1999). Nonetheless, assessments can be adapted to increase students' engagement with professional genres and Discourse Communities. Such changes could include asking students to disseminate aspects they learned to non-expert audiences, in a blog, or to a sales team in a company. Another possibility is to create situations where they address other professionals directly, for example by creating assignments based on real industry challenges, which would allow students to submit their texts for the official challenge and HE assessment. Yet again, those teaching writing cannot be the driving force of such curricular developments; an Academic and Professional Literacies approach could only provide them with a tool to support increased engagement with professional Discourse Communities of practice in post-92 universities.

The examination of potential difficulties shows that the proposed development of an Academic and Professional Literacies framework does not only depend heavily on changes in curriculum design, and is thus beyond the influence of writing practitioners. It also touches on far broader and highly complex questions about the role and purpose of HE in contemporary society. For a proposal of such complexity and scope, it is impossible to ignore the question of whether such a conceptual development is ultimately 
desirable - and possible. We do not claim that this paper can give a definitive answer to this question, but we think that there are strong reasons why this is a significant endeavour. To support our view that the possibility deserves further thought and research, we will provide a broad outline of research that will be necessary to advance our tentative proposal. While this confirms the scope and complexity, it also demonstrates that immediate further steps are possible and not entirely beyond the influence of writing practitioners. After this outline, we therefore conclude this paper with an appeal for further research and the reasons why we consider this to be important.

\section{Further Research}

As explained above, Academic Literacies already refers to a multiplicity of literacies, which means that it is open to expanding its scope towards professional literacies on a theoretical level. Nonetheless further theoretical research is needed to gain a more precise understanding of the concepts to be included in the framework. Literature on professional communities, identities and discourses can make an important contribution to this work (e.g. Beaufort 2008 or Henry 2000), especially publications such as Dias et al. (1999), which directly compare the two contexts for writing. The latter already identifies some of the intrinsic differences between the purpose of writing in $\mathrm{HE}$ and the workplace. A wider review of the literature (e.g. Francis. 2016) can lead to further comparison of the values and underlying assumptions that shape written communication across and in specific professional communities. Where available existing approaches to teaching professional writing should also be considered. They implicitly reflect the roles and tools that are available to participants in professional discourse communities as well, and allow an insight into explicit instruction provided for novice writers in these contexts. 
In parallel to the theoretical work outlined above, further research can focus on developing practice in teaching both academic and professional writing. An important step to create more opportunities for such teaching would be to develop occasions for writing that is not primarily academic, but allows students the possibility to take on roles as, or at least similar to, writing professionals. Focusing on programmes of study where all, or the majority of students, already have two identities, one as a student, one as a professional in their field, could be a way of using existing programme structures where both contexts are already present. Although their number is more limited than 'traditional' undergraduate degrees, it is growing, as universities develop degrees tailored to the professional development needs of specific sectors or companies. At GCU, for example, the School for Work Based Education operates in a university to business environment, which offers graduate programmes to clients, including SSE, North and South Lanarkshire Councils and Transnet Freight Rail (South Africa). That is, people already in employment enter HE to obtain an academic qualification. Locating research in these existing structures would make it possible to develop practice in teaching across different academic and professional genres. Any insights from this research could inform the development other programmes of study.

\section{Conclusion}

The outline of potential further research is far too imprecise at this stage for a specific research programme that charts the way from this initial proposal to the successful development of an Academic and Professional Literacies framework. At the same time it demonstrates that initial steps in the process of developing a fuller, more detailed proposal for this conceptual development are possible in the current situation. In other words, it is not necessary to address the big, underlying questions first. Instead, smaller studies focussing on the teaching of writing can act as first steps towards addressing 
these questions - the initial steps of the path are feasible, and we would argue that it is path worth taking for two reasons: our ethical responsibilities towards our students, and our belief in the transformative power of education.

Our ethical responsibilities towards our students mean that we cannot ignore their own wishes, ambitions and motivations. It cannot be acceptable for us to 'impose' the aim of developing their peripheral participation in academic communities towards full participation onto our students, regardless of their own priorities and their own desired identities. An emancipatory approach, such as Academic Literacies, needs to respect students' self-determination and desired identities. If our observations and reflection based on work at a post-92 university ${ }^{4}$ suggest that their own aims are not reflected in the aims of an Academic Literacies approach, we have to accept that this conceptual framework, in its current form, might not be suitable to this context.

For those of us who teach writing, and are committed to the notion of HE as a transformative process this creates an uncomfortable ethical situation: we can either abandon our theoretical framework or adjust it. The observation presented in this paper suggests that students are willing and interested in engaging with language and communication in a more holistic and critical way, as long as they can see the relevance for their professional, rather than their academic identities. In other words, teaching writing could still be a transformative process that helps them engage more critically with the Discourse Communities around them, as long as we accept their choice of Discourse Communities. Developing an Academic and Professional Literacies approach is thus the most promising way of reconciling our students' aims with ours, and of matching their

\footnotetext{
${ }^{4}$ Further experience that indicates that students' interest in developing writing is influenced by a desire to improve their marks rather than thoroughly understanding, or even challenging the conventions of academic discourse communities has been discussed in Canton (2014).
} 
and our understanding of the purpose of education. At the same time, this work could help to address bigger questions about (1) the underlying schism between our view of education as a transformative experience and a HE landscape where market values are gaining in importance, and (2) the purpose of HE for our students and the role it fulfils in society. The proposed conceptual development could join a growing body of research that indirectly addresses these questions from a range of different angles. Work as diverse as Rebeka Nathan's anthropological study of contemporary student life at a US college (Nathan 2005) or Courtney J. Campbell's (2017) investigation into the relevance of Paulo Freire's work for contemporary undergraduate degrees implicitly addresses the same underlying questions. Through developing an Academic and Professional Literacies framework for the teaching of writing in HE, we could indirectly contribute to this conversation about the purpose of our work.

Just as importantly, such a revised conceptual framework could also increase the chance of achieving our more immediate aims, i.e. to make our teaching a transformative experience for our students that enables them to deal critically and creatively with language and the realities it creates: once acquired, the ability to analyse and then manipulate language can be used by students and graduates to conform to predominant power relationships, or to challenge them. Most likely they will use this ability for each of these purposes at different times in their student and working life, but they might be more motivated to challenge power structures in contexts that matter to them, hence predominantly in professional contexts. The emancipatory ideal of Academic Literacies is not abandoned in an Academic and Professional Literacies approach, but, perhaps, merely postponed.

Acknowledgements: The authors would like to thank the colleagues who offered invaluable feedback on earlier drafts of this paper. 


\section{References}

Anson, Chris M. and Forsberg, L. Lee. 1990. "Moving Beyond the Academic Community." Written Communication. 7(2): 200-31

Archer, Will and Davison, Jess. 2008. Graduate Employability. The View of Employers. Council for Industry and Higher Education. http://www.brunel.ac.uk/services/pcc/staff/employability/?a=92718

Askehave, Inger and Swales, John M. 2001. "Genre Identification and Communicative Purpose: a Problem and a Possible Solution.” Applied Linguistics. 22 (2): 195 212

Beaufort, Anne. 2008. "Writing in the Professions." In Handbook of Research on Writing. History, Society, School, Individual, Text. edited by Charles Bazerman. 269289. New York and London: Lawrence Erlbaum Associates. Taylor and Francis

Biggs, John and Tang, Catherine. 2007. Teaching for Quality Learning at University. Maidenhead: McGraw Hill.

Borg, Erik and Deane, Mary. 2011. "Measuring the Outcomes of Individualized Writing Instruction: a Multi-layered Approach to Capturing the Changes in Students' Texts.” Teaching in Higher Education. 16 (3): 139 - 331

Campbell, Courtney J. 2017. A Pedagogy of the Undergraduate: Applying Paulo Freire's Educational Project to Higher Education. Presentation at the University of Birmingham, March, 15.

Canton, Ursula. 2014. "The Impact of the Academic Literacies Model on the Provision of Academic Writing Support.” Reflecting Education. 9(1): 52-62. http://www.reflectingeducation.net/index.php/reflecting/article/view/124/128

Catt, Robert and Gregory, Gerry. 2006. "The Point of Writing: Is Student Writing in Higher Education Developed or Merely Assessed?" In: Teaching Academic Writing in UK Higher Education. edited by Lisa Ganobcsik-Williams. Houndsmill: Palgrave

Clark, Romy and Ivanič, Roz. 1991. "Consciousness-raising about the writing process." In: Language Awareness in the Classroom. Edited by Carl James and Peter Garrett. $168-85$. London and New York: Longman 
Coffin, Caroline and Donohue, James. P. 2012. "Academic Literacies and systemic functional linguistics: How do they relate?" Journal of English for Academic Purposes. 11: $64-75$

Davies, Ben. 2009. "What are Employers Looking for?” Jobs.ac.uk http://www.jobs.ac.uk/careers-advice/interview-tips/1337/what-are-employerslooking-for-skills-and-qualifications/.

Deane, Paul, Odendahl, Nora, Quinlan, Thomas, Folwes, Mary, Welsh, Cyndi and Bivens-Tantum, Jennifer. 2008. Cognitive Models of Writing: Writing Proficiency as Complex Integrated Skills. ETS. http://dx.doi.org/10.1002/j.2333$\underline{\text { 8504.2008.tb02141.x }}$

Dearnley, C. and Matthew, B. 2007 "Factors that Contribute to Undergraduate Student Success.” Teaching in Higher Education 12 (3): 377 - 91

Diamond, Abigail, Walkely, Liz, Forbes, Peter, Highes, Tristam and Sheen, Jonathan. 2011. Global Graduates into Global Leaders. http://www.agcas.org.uk/agcas resources/401-Global-Graduates-into-Global$\underline{\text { Leaders }}$

Dias, Patrick, Freedman, Aviva, Medway, Peter, Paré, Anthony. 1999. Worlds Apart. Acting and Writing in Academic and Workplace Contexts. Mahwah and London: Lawrence Erlbaum Associates

Francis, Ann Marie. 2016. Composition Assignments with Workplace Relevance. $\mathrm{PhD}$ diss., Georgia State University. http://scholarworks.gsu.edu/cgi/viewcontent.cgi?article=1175\&context=english $\underline{\text { diss }}$

Freire, Paulo. 1985. The Politics of Education. transl. Donaldo Macedo. Houndsmill: Macmillan

Ganobcsik-Williams, Lisa. 2006. "New Contexts, New Challenges: The Teaching of Writing in UK Higher Education." in: Teaching Academic Writing in UK Higher Education. edited by Lisa Ganobcsik-Williams. 6 - 15. Houndsmill: Palgrave

GCHQ. 2014. Call for Applications for Certified Master's in Cyber Security. https://www.cesg.gov.uk/awarenesstraining/academia/Pages/MastersDegrees.aspx. Accessed 07.05.15 
GCU. 2013. Programme Specification: Masters of Engineering in Digital Security, Forensics \& Ethical Hacking. Unpublished Document

Gee, James Paul. 1999. An Introduction to Discourse Analysis. Theory and Method. London and New York: Routledge

Gee, James Paul. 2008. Social Linguistics and Literacies. Ideologies in Discourses. $3^{\text {rd }}$ edition. London and New York: Routledge

Gourlay, Lesley. 2009. “Threshold Practices: Becoming a Student through Academic Literacies." London Review of Education. 7(2): 181-92

Govan. Michelle. 2014a. The Application of Peer Teaching in Digital Forensics Education. Innovations In Teaching And Learning In Information And Computer Science. doi: 10.11120/ital.2014.00012

Govan, Michelle. 2014b. Enhancing Student Experience \& Employability via External Inputs into the Curriculum. HEA STEM Annual Learning and Teaching Conference: Enhancing the STEM Student Journey.

https://www.heacademy.ac.uk/resources/detail/stem-conference2014/Post_event_resources/Computing/Enhancing_student_experience

Henry, Jim. 2000. Writing Workplace Cultures. An Archaeology of Professional Writing. Carbondale: Southern Illinois UP

Hyland, Ken. 2005. Metadiscourse. Exploring Interaction in Writing. London and New York: Continuum

Irons, Alaisdair, D., Stephens, Paul and Ferguson, R.I. 2009. "Digital Investigation as a Distinct Discipline: A Pedagogic Perspective”. Digital Investigation. 6: 82 - 92 doi: $10.1016 /$ j.diin.2009.05.002

Ivanič, Roz. 1998. Writing and Identity. Amsterdam: John Benjamins

Kezar, Adrianna and Bernstein-Sierra, Samantha. 2016. 'Commercialisation in Higher Education'. in: Handbook of Academic Integrity. edited bu Tracey Bretag. 325 346. Singapore: Springer Science and Business

Klein, Perry D., Boscolo, Pietro. (2016). "Trends in research on writing as a learning activity." Journal of Writing Research, 7(3), 311- 350. doi: 10.17239/jowr2016.07.3.01 
Lave, Jean and Wenger, Etienne. 1991. Situated Learning. Legitimate Peripheral Participation. Cambridge: UP

Lea, Mary R. 2005. “Communities of Practice' in Higher Education. Useful Heuristic or Educational Model.” In: Beyond Communities of Practice : Language, Power and Social Context. edited by David Barton and Karen Tusting. $180-197$. Cambridge: UP

Lea, Mary R. and Street, Brian. 1998. "Student Writing in Higher Education. An Academic Literacies Approach." Studies in Higher Education. 23 (2): 157 - 175 doi: $10.1080 / 03075079812331380364$

Lee, David YW. 2001. “Genres, Registers, Text Types, Domains and Styles: Clarifying the Concepts and Navigating a Path through the BNC Jungle." Language Learning \& Technology. 5 (3): 37-72 http://1t.msu.edu/vol5num3/lee/default.html

Leibowitz, Brenda, Goodmann, Kenneth, Hannon, Peter and Parkerson, Andrea. 1997. The Role of a Writing Centre in Increasing Access to Academic Discourse in a Multilingual University. Teaching in Higher Education. 2 (1): 5 - 19. doi: $10.1080 / 1356251970020101$

Lillis, Theresa M. 2001. Student Writing: Access, Regulation, Desire. London: Routledge

Lillis, Theresa. 1997. "New Voices in Academia? The Regulative Nature of Academic Writing Conventions." Language and Education. 11 (3): 182 - 99

McAndrew, Donald A., Reigstad, Thomas J. and Strickland, James. 2001 Tutoring Writing. Portsmouth, NH: Heinemann

Middleton, Diana. 2011. Students Struggle for Words. The Wall Street Journal. http://www.wsj.com/articles/SB100014240527487034099045761746517801109 $\underline{70}$.

Nathan, Rebekah. 2005. My Freshman Year. What a Professor Learned by Becoming a Student. Ithaca and London: Cornell UP

The New London Group. 1996. “A Pedagogy of Multiliteracies: Designing Social Futures." Harvard Educational Review.1996 (1): 60 - 92 
Palmer, Gary. 2001. A Road Map for Digital Forensic Research. The First Digital Forensic Research Workshop (DFRWS) http://www.dfrws.org/2001/dfrws-rmfinal.pdf

Purdue University. 2013. 'Higher Order Concerns (HOCs) and Lower Order Concerns (LOCs)'. Purdue Owl. https://owl.english.purdue.edu/owl/resource/690/01/

Reaney, M. 2016. 'Employability Skills'. Gradvert Blogs.

http://gradvert.com/universities/employability-skills-how-to-provide-studentswith-an-education-that-secures-them-a-graduate-job/\#

Rukhsana, Ahmad and MacMahon, Katharine. 2006. 'The Benefits of Good Writing'. In: Writing Matters. The Royal Literary Fund Report into Student Writing in Higher Education.edited by Steven Davies, David Swinburn and Gwenno Williams. 1-7. London: Royal Literary Fund

Schön, Donald A. 1991. The Reflective Practitioner. How Professionals Think in Action. Second edition. Aldershot: Arena

Swales, John M. 1990. Genre Analysis. English in Academic and Research Settings. Cambridge: UP

Tennenbaum, Rosa. 2012 'Bildung zum schönen Charakter'. Humboldt. Eine Publikation des Goethe Instituts. http://www.goethe.de/wis/bib/prj/hmb/the/158/de10444028.htm

Tripp, David. 1993. Critical Incidents in Teaching. Developing Professional Judgement. New York and London: Routledge

UK Government. 2011. The UK Cyber Security Strategy. http://www.enisa.europa.eu/activities/Resilience-and-CIIP/national-cybersecurity-strategies-ncsss/UK_NCSS.pdf.

Yanow, Dvora. 2007 "Interpretation in Policy Analysis: On Methods and Practice." Critical Policy Studies, 1:1, 110-122, DOI: 10.1080/19460171.2007.9518511 
Table 1. Students' evaluation of the workshops: Aspects they found most / least useful and skills they applied later in different contexts. Nr. of participants $=11$; rows with fewer answers include $\mathrm{n} / \mathrm{a}$ responses.

\begin{tabular}{|l|l|l|l|}
\hline Nr. of students who & $\begin{array}{l}\text { Writing as Commu- } \\
\text { nication }\end{array}$ & $\begin{array}{l}\text { Mechanics of Writ- } \\
\text { ing }\end{array}$ & $\begin{array}{l}\text { Genre Conventions } \\
\text { (e.g. Using Sources) }\end{array}$ \\
\hline $\begin{array}{l}\text { found this most use- } \\
\text { ful }\end{array}$ & 3 & 6 & 2 \\
\hline $\begin{array}{l}\text { found this least use- } \\
\text { ful }\end{array}$ & 4 & 1 & 0 \\
\hline $\begin{array}{l}\text { used the insights } \\
\text { gained in other con- } \\
\text { texts }\end{array}$ & 2 & 5 & 1 \\
\hline
\end{tabular}

